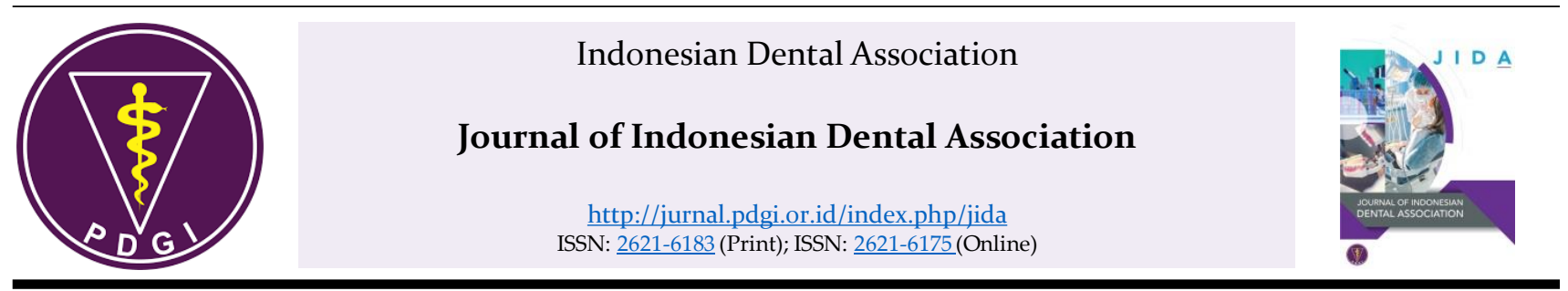

Research Article

\title{
The Effect of Audiovisual \\ Dissemination on Students $13-14$ Years Old to Oral Hygiene Status
}

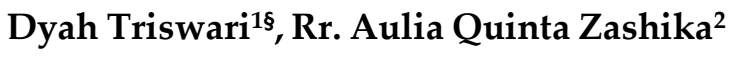 \\ ${ }^{1}$ Dental Study Program, Universitas Muhammadiyah Yogyakarta, Indonesia \\ 2 Undergraduate Student of Dental Study Program, Universitas Muhammadiyah Yogyakarta
}

Received date: August 1, 2019. Accepted date: October 4, 2018. Published date: October 31, 2019

\section{KEYWORDS \\ oral hygiene status; OHI-S; \\ audiovisual media}

\begin{abstract}
Introduction: Dental and oral health problems in children, especially caries, increase at age 10-14 years old due to the lack of children's knowledge. Knowledge can be provided through dissemination. Dissemination can be delivered by audio-visual media that is easy to be understand and remember. Objective: To determine the influence of dissemination using audio-visual media on 13-14 years old students at Islamic Center Bin Baz Yogyakarta Boarding School (ICBB) of oral hygiene status. Methods: This research used experimental quasy method with one group pre-test and post-test design on 60 subjects at ICBB. Pre-test and post-test assessments include oral hygiene status measurement before and after the dissemination. These studies lasted 35 days with three times dissemination repetition within 14 days interval. Paired Simple T-Test was used as data analysis method. Result: The average of oral hygiene status using Simplified Oral Hygiene Index (OHI-S) decreased from 2,58 to 0,96. The result retrieved from Paired Simple T-Test obtained $\mathrm{p}$ value $0,000(\mathrm{p}<0,05)$ showed that there was significant difference of oral hygiene status average before and after the dissemination was delivered. Conclusion: This study showed that audio-visual media dissemination may affect oral hygiene status on students 13-14 years old at Salafiyah Wustha Islamic Center Bin Baz Yogyakarta Islamic Boarding School.
\end{abstract}

\footnotetext{
${ }^{\S}$ Corresponding Author

E-mail address: dyahtriswari@gmail.com (Triswari D)
} 


\section{KATA KUNCI}

kebersihan gigi dan mulut; OHI-S;

media audiovisual

\section{PENDAHULUAN}

Faktor yang berpengaruh besar terhadap kejadian penyakit rongga mulut adalah kebersihan gigi dan mulut atau oral hygiene. Keadaan rongga mulut tanpa akumulasi debris, plak, materia alba, dan stain gigi merupakan kebersihan gigi dan mulut yang baik. Status kebersihan gigi dan mulut dapat dinilai dengan pemeriksaan indeks Oral Hygiene Index-Simplified (OHI-S). ${ }^{1}$

Indeks kebersihan mulut OHI-S merupakan salah satu penilaian kebersihan mulut yang terukur menurut Greene dan Vermillion. Terdapat 6 gigi yang digunakan untuk mengukur OHI-S, yaitu molar pertama kanan dan kiri bawah, insisivus kanan atas dan insisivus kiri bawah, serta molar pertama kanan dan kiri atas. Pengukuran OHI-S dilakukan dengan menjumlahkan skor Debris Index Simplified (DI-S) dan Calculus Index Simplified (CI-S) yang diperoleh dengan pengukuran debris dan kalkulus yang menempel pada permukaan gigi. ${ }^{2}$

Pendidikan kesehatan gigi dan mulut merupakan salah satu kegiatan yang dapat membantu pemeliharaan kesehatan gigi dan mulut dengan meningkatkan pengetahuan kesehatan gigi dan mulut. Penyuluhan merupakan bentuk usaha untuk meningkatkan pengetahuan dalam memelihara kesehatan gigi dan mulut. Selain itu, penyuluhan merupakan usaha penyampaian informasi untuk mengarahkan suatu perubahan perilaku yang diharapkan. ${ }^{3}$ Perilaku berperan penting terhadap kesehatan gigi dan mulut.

Media audiovisual merupakan salah satu media penyuluhan yang bersifat dapat didengar dan dilihat. Media audiovisual, melalui gambar bergerak dan suara yang melibatkan indera penglihatan dan pendengaran, dapat menyampaikan informasi lebih nyata. Sasaran pendidikan akan dapat memahami dan mengingat informasi yang telah diberikan akan semakin besar kemungkinannya apabila semakin banyak pula indera yang digunakan untuk merekam informasi tersebut. ${ }^{4}$ Film animasi merupakan media audiovisual yang dapat dimanfaatkan untuk penyuluhan dan dapat memicu keingintahuan dan ketertarikan pada sasaran pendidikan terhadap hal-hal yang dipelajari. ${ }^{5}$

Remaja memiliki tingkat kesadaran yang lebih tinggi daripada anak-anak sehingga membuat remaja tepat menjadi target penyuluhan. ${ }^{6}$ Usia remaja berkisar antara 12 sampai 23 tahun. Usia 13-14 tahun merupakan usia di masa transisi dari remaja awal ke remaja pertengahan dan sudah mampu berpikir secara efektif dan sistematis menurut teori Piaget tentang perkembangan kognitif anak. Ingatan pada anak yang mencapai intensitas terbesar dan terkuat adalah pada usia 10-14 tahun. ${ }^{7}$

Pondok pesantren adalah lembaga pendidikan yang pengajarannya mengenai pendidikan diniyah islamiyah dan pendidikan umum secara terpadu. Tersedia pondok yang merupakan asrama dimana para santri tinggal bersama dibawah naungan pengajar yang biasa disebut dengan ustadzah. Santri pada pondok pesantren memiliki jam biologis yang sama, serta pola dan jenis makanan yang dikonsumsi relatif sama, dan kesempatan untuk mengunjungi dokter gigi kemungkinan lebih sedikit dibandingkan dengan siswi pada sekolah yang tidak berasrama, sehingga dapat memperkecil kemungkinan terjadinya bias terhadap hasil yang akan diperoleh. Penelitian menunjukan bahwa waktu yang dibutuhkan untuk mencapai $95 \%$ perubahan perilaku berkisar antara 18 sampai 254 hari. Hal ini menunjukkan variasi yang cukup besar dalam berapa lama waktu yang dibutuhkan 
setiap orang untuk menjadikan sebuah pengetahuan menjadi sebuah kebiasaan, akan tetapi pemberian pengetahuan dan pengulangan perilaku yang konsisten dapat meningkatkan dan mempercepat otomatisasi pembentukan kebiasaan pada individu. ${ }^{8}$

\section{METODE}

Penelitian ini merupakan penelitian eksperimental semu (Quasy Experimental) dengan One Group Pre-test and Post-test Design. Subyek dari penelitian adalah 60 santriwati usia 13-14 tahun di Salafiyah Wustha Pondok Pesantren Islamic Center Bin Baz (ICBB) Yogyakarta yang memenuhi kriteria inklusi. Teknik pengambilan sampel yang digunakan adalah Purposive Sampling dimana responden sudah memenuhi sampel minimal dan disesuaikan dengan kriteria inklusi yang telah ditentukan. Status kebersihan gigi dan mulut diukur dengan menggunakan Oral Hygiene Index-Simplified (OHI-S).

Penelitian ini menggunakan metode quasy experimental one group pre-test and post-test design pada 60 subyek di ICBB. Penilaian pre-test dan post-test meliputi pengukuran status kebersihan gigi dan mulut sebelum dan setelah penyuluhan. Studi ini berlangsung selama 35 hari dengan tiga kali pengulangan penyuluhan setiap 14 hari. Analisis data menggunakan uji Paired Sample T-Test.

OHI-S dilakukan dengan mengukur daerah permukaan gigi yang tertutup oleh debris dan kalkulus dengan menjumlahkan Debris Index Simplified (DI-S) dan Calculus Index Simplified (CI-S) (Greene dan Vermillion, 1964). ${ }^{9}$ Kriteria penilaian OHI-S dengan skor 0 - 1,2 termasuk kategori baik, 1,3 - 3 termasuk kategori sedang dan 3,1 - 6 termasuk kategori buruk. Gigi-gigi yang akan diukur yaitu gigi 16 pada permukaan bukal, gigi 11 pada permukaan labial, gigi 26 pada permukaan bukal, gigi 36 pada permukaan lingual, gigi 31 pada permukaan labial, dan gigi 46 pada permukaan lingual.

Penyuluhan dengan media audiovisual, merupakan pendidikan kesehatan gigi dan mulut yang disajikan dengan menggunakan media audiovisual menggunakan video penyuluhan kesehatan gigi dan mulut yang dibuat oleh Maya Angela dari Fakultas Kedokteran Gigi Universitas Gadjah Mada berjudul "Mengenal Gigi Bersama Dimas dan Disya". Film animasi ini berdurasi 10 menit dan telah teruji validitasnya. ${ }^{10}$

Analisis data yang digunakan pada penelitian ini adalah analisis data deskriptif atau univariat dan analisis data bivariat. Analisis data deskriptif adalah untuk melihat rata-rata atau mean dari skor OHI-S. Analisis bivariat yang digunakan pada penelitian ini adalah uji $\mathrm{t}$ berpasangan atau Paired Sample t-Test. Analisis ini digunakan untuk mengetahui pengaruh penyuluhan media audiovisual terhadap status kebersihan gigi dan mulut OHI-S.

\section{HASIL}

Seluruh subyek penelitian dikelompokkan berdasarkan usia, subyek yang berusia 13 tahun sebanyak 45 orang dan 14 tahun sebanyak 15 orang (Tabel 1).

Tabel 2 menunjukkan rata-rata status kebersihan gigi dan mulut OHI-S sebelum dan setelah diberikan penyuluhan tentang kesehatan gigi dan mulut menggunakan media audiovisual yang dilakukan sebanyak 3 kali selama 35 hari di Pondok Pesantren ICBB Yogyakarta. Berkurangnya nilai tersebut menggambarkan terjadinya penurunan status kebersihan gigi dan mulut setelah diberikan penyuluhan.

Berdasarkan Tabel 3 dapat dilihat bahwa nilai probabilitas sebelum dan setelah diberikan penyuluhan adalah 0,000 . Nilai $\mathrm{p}<0,05$ berarti terdapat perbedaan yang signifikan antara status kebersihan gigi dan mulut OHI-S sebelum dan sesudah diberikan penyuluhan dengan media audiovisual.

Tabel 1. Distribusi sampel berdasarkan kelompok usia

\begin{tabular}{ccc}
\hline Kelompok Usia & Jumlah & Persentase \\
\hline 13 Tahun & 45 & $75 \%$ \\
14 Tahun & 15 & $25 \%$ \\
\hline Total & 60 & $100 \%$ \\
\hline
\end{tabular}

Tabel 2. Rata-rata status kebersihan mulut

\begin{tabular}{cccc}
\hline $\begin{array}{c}\text { Waktu } \\
\text { Penelitian }\end{array}$ & $\begin{array}{c}\text { Jumlah } \\
\text { Sampel }\end{array}$ & $\begin{array}{c}\text { Rata - Rata } \\
\text { Skor OHI-S }\end{array}$ & $\begin{array}{c}\text { Standar } \\
\text { Deviasi }\end{array}$ \\
\hline $\begin{array}{c}\text { Sebelum } \\
\text { penyuluhan }\end{array}$ & 60 & 2,5888 & 1,21698 \\
$\begin{array}{c}\text { Setelah } \\
\text { penyuluhan }\end{array}$ & 60 & 0,9653 & 1,20567 \\
\hline
\end{tabular}

Tabel 3. Hasil analisis uji paired sample T-Test Status OHI-S

\begin{tabular}{ccc}
\hline Status OHI-S & N & Nilai p \\
\hline $\begin{array}{c}\text { Sebelum dan sesudah } \\
\text { penyuluhan }\end{array}$ & 60 & 0,000 \\
\hline
\end{tabular}




\section{PEMBAHASAN}

Usia 13 tahun merupakan batasan akhir usia pada masa remaja awal, sedangkan usia 14 tahun merupakan batasan usia awal pada masa remaja pertengahan. Ingatan pada anak usia 10-14 tahun mencapai intensitas paling besar dan paling kuat. Anak usia lebih dari 11 tahun mengalami beberapa perkembangan kognitif yaitu mereka sudah mampu berpikir abstrak, melakukan penalaran terhadap sebuah situasi nyata yang digunakan untuk mengambil kesimpulan lalu diterapkan pada masalah yang dihadapinya. Anak usia 13-14 tahun sudah mampu berpikir secara efektif dan sistematis menurut teori Piaget tentang perkembangan kognitif anak. ${ }^{8}$

Tabel 3 menunjukkan adanya perbedaan yang signifikan antara sebelum dan setelah diberikan penyuluhan yang artinya terdapat pengaruh penyuluhan media audiovisual pada santriwati usia 13-14 tahun di Pondok ICBB Yogyakarta terhadap status kebersihan gigi dan mulut OHI-S. Rata-rata skor OHI-S pada saat sebelum diberikan penyuluhan termasuk dalam kategori buruk sedangkan setelah diberikan penyuluhan termasuk ke dalam kategori sedang. Penelitian ini sejalan dengan penelitian sebelumnya bahwa terjadi penurunan skor rerata DI-S sesudah penyuluhan kesehatan gigi dan mulut karena media audiovisual merupakan media yang paling efektif untuk menarik minat, meningkatkan pengetahuan dan mengubah perilaku menyikat gigi pada penderita Schizophrenia. Hal ini juga sejalan dengan teori Edgar Dale bahwa semakin konkrit media maka tingkat penerimaan sasaran menjadi lebih baik, sebaliknya semakin abstrak sebuah media maka tingkat penerimaan menjadi kurang. ${ }^{2}$

Peningkatan pengetahuan dan perubahan perilaku dapat mendukung penurunan skor OHI-S. Perubahan perilaku responden dapat meliputi tata cara membersihkan gigi seperti membersihkan gigi dengan menggunakan sikat dan pasta gigi, menyikat gigi dua kali sehari, menyikat gigi setelah makan pagi dan sebelum tidur malam, mengunjungi dokter gigi enam bulan sekali, dan menggunakan pasta gigi yang mengandung fluoride.

Penyuluhan adalah salah satu faktor yang mempengaruhi meningkatnya kemampuan kognitif seseorang yang dapat memberikan rangsangan agar obyek diingat kembali dan dapat memberikan input baru yang menambahkan atau meluruskan memori yang telah disimpan. ${ }^{11}$ Hal ini dapat membantu keberhasilan penelitian, salah satu upaya untuk meningkatkan kebersihan gigi dan mulut diperlukan adanya penyuluhan.

Penyuluhan tentang kesehatan gigi dan mulut dilakukan dengan menggunakan media audiovisual yang sebelumnya dilakukan pengukuran status OHI-S terlebih dahulu. Penyuluhan dilakukan sebanyak tiga kali yaitu penyuluhan pertama setelah pengukuran awal, 14 hari setelah penyuluhan pertama, dan 14 hari setelah dilakukannya penyuluhan kedua. Penyuluhan merupakan usaha untuk menyampaikan informasi yang membimbing ke arah suatu perubahan perilaku yang diharapkan. ${ }^{4}$ Perilaku dianggap menjadi suatu kebiasaan jika dilakukan secara rutin paling tidak 10 kali dalam satu bulan. ${ }^{12}$

Keberhasilan media audiovisual dalam menurunkan status kebersihan gigi dan mulut OHI-S dalam penelitian ini didukung oleh beberapa hal diantaranya responden yang kooperatif dan memperhatikan dengan saksama informasi yang disampaikan dalam film animasi serta suasana ruangan yang kondusif. Penelitian lain yang serupa dan mendukung, juga pernah dilakukan oleh Luluq Edyati, hasil penelitian menunjukkan adanya pengaruh yang signifikan dari penyuluhan kesehatan tentang personal hygiene dengan media video terhadap pengetahuan dan sikap personal hygiene siswa. ${ }^{13}$ Media audiovisual dapat menyampaikan pengertian atau pengetahuan secara nyata melalui gambar bergerak dan suara. $^{5}$

Hal ini sejalan dengan teori bahwa media visual membantu menstimulasi indra mata dan media audio membantu menstimulasi alat indra pendengaran pada waktu proses penyampaian pesan. Diharapkan dengan digunakannya media audiovisual pesan yang disampaikan dapat diingat semaksimal mungkin, sehingga dapat mempengaruhi perilaku sehat pendengar. Penggunaan media sebagai alat bantu penyampai pesan membantu jalannya proses komunikasi. Peranan dan fungsi media sangat dipengaruhi oleh ruang, waktu, pendengar dan sarana prasana yang tersedia disamping sifat dari media tersebut. ${ }^{12}$ Penggunaan metode OHI-S pada penelitian ini dikarenakan selain dapat menunjukkan status kebersihan gigi dan mulut, metode ini juga mudah digunakan serta membutuhkan waktu yang singkat dalam penggunaannya. OHI-S juga dapat menilai kegiatan kesehatan gigi dari masyarakat serta menilai efek segera dan jangka panjang dari pendidikan kesehatan gigi. ${ }^{14}$

\section{KESIMPULAN}

Berdasarkan penelitian yang telah dilakukan dapat disimpulkan bahwa penyuluhan media audiovisual pada pelajar usia 13-14 tahun di Pondok Pesantren Islamic Center Bin Baz Yogyakarta mampu menurunkan status kebersihan gigi dan mulut OHI-S.

\section{KONFLIK KEPENTINGAN}

Penulis menyatakan tidak terdapat konflik kepentingan yang berkaitan dengan manuskrip ini. 


\section{REFERENCE}

1. Newman GM, Takei HH, Klokkevold RP, editors. Carranza's clinical periodontology. 10th ed. Philadelphia: Saunders Elsevier; 2006.

2. Suproyo H. Penatalaksanaan penyakit jaringan periodontal. 2nd ed. Yogyakarta: Kanwa Publisher; 2009.

3. Herijulianti E, Indriani ST, Artini S, editor. Pendidikan kesehatan gigi. Jakarta: EGC; 2002.

4. Tandilangi M, Mintjelungan C, Wowor VNS, editor. Efektivitas dental health education dengan media animasi kartun terhadap perubahan perilaku kesehatan gigi dan mulut Siswa SD Advent 02 Sario Manado. Jurnal e-GiGi. 2016;4(2):106-110.

5. Andriany P. Perbandingan efektivitas media penyuluhan poster dan kartun animasi terhadap pengetahuan kesehatan gigi dan mulut. Journal of Syiah Kuala Dentistry Society. 2016;1(1):21-28.

6. Felton A, Chapman A, Felton S. Basic guide to oral health education and promotion. Hoboken (NJ): Wiley-Blackwell; 2009.

7. Santrock JW. Masa perkembangan anak. 2nd ed. New York: McGraw-Hill; 2009.

8. Lally P, Jaarsveld CHMV, Potts HWW, Wardle J. 2009 How are habits formed: modelling habit formation in the real world. Eur $\mathrm{J}$ Soc Psychol. 2009;40:998-1009.
9. Greene JC, Vermilion JR. The simplified oral hygiene index. J Am Dent Assoc. 1964;68:713.JDent Assoc. 1964;68:7-13.

10. Angela M. Perbandingan perubahan pengetahuan anak usia 10-12 tahun pada promosi kesehatan gigi dan mulut antara metode ceramah dengan media poster dan metode diskusi dengan media booklet dan audiovisual. [Skripsi]. Yogyakarta: Universitas Gajah Mada. 2015.

11. Prabhu S, John J. Oral health education for improving oral health status of school children - a systematic review. IOSR Journal of Dental and Medical Sciences. 2015;14(2):101-106.

12. Hadnyanawati H. Pemanfaatan multimedia sebagai media penyuluhan kesehatan gigi. Indonesian Journal of Dentistry. 2007;14(3):177-180.

13. Edyati L, Khusnal E. Pengaruh penyuluhan kesehatan dengan media video terhadap pengetahuan dan sikap personal hygiene siswa SD Negeri 1 Kepek Pengasih Kulon Progo. [Skripsi]. Yogyakarta: STIKES 'Aisyiyah. 2014.

14. Putra RK, Kusumo E, Nurhayati S. Efektivitas pembelajaran dengan pendekatan keterampilan proses dasar menggunakan media audio visual. Chem in Edu. 2013;2(1):1-8. 